\title{
Impact of Public Spending on the Quality of Life in Rural Bangladesh
}

\author{
Zannatul Fardoush \\ Bangladesh Bank (the Central Bank of Bangladesh)
}

\begin{abstract}
Public spending is one of the most effective instruments in improving the quality of life as an entrenched goal of economic development. However, as the resources are limited, a better distribution would, therefore, require a thorough investigation regarding the impact analysis of public spending on actual development factors. This paper has examined the link between public expenditures in different sectors of economy and improvement in the quality of life through the channel of agricultural growth or rural development in Bangladesh and also throughs the education channel such as the school enrollments. A simultaneous equation model in the form of a 3-Stage Least Square (3SLS) technique has been used to explore the impacts of public spending. By using the data from 1982-2017, this study finds that public spending in education, health, social safety net, and agriculture has positive impacts on the quality of life advancement. A 1 percent increase in public spending in education would result in an increase in quality of life (proxied by life expectancy) by 0.182 percent on average, ceteris paribus. The public expenditure elasticities in health, social safety net, and agriculture on the quality of life are found as $0.05,0.03,0.04$ respectively. The only concern is the spending in the transportation and communication sector which is probably due to the misallocation and mismanagement of available resources and funds into this sector. Hence, to grasp the agricultural and rural development, the government should continue to institutionalize the policies that support the education of the poor in rural areas
\end{abstract}

INTRODUCTION

Public spending is one of the most effective instruments in improving the quality of life as an entrenched goal of economic development. It is inevitable in promoting agricultural growth and reducing poverty especially in rural areas of developing countries. Along with the government expenditure in the agriculture sector, rural development or agricultural growth also depends upon non-agriculture expenditures such as rural infrastructure, health, education, social welfare or even transportation. Since these investments may have differential productivity and poverty reduction effects, it is important to evaluate the spending in these sectors. Moreover, since the resources are limited, a better distribution would, therefore, require a thorough investigation regarding the impact analysis of public spending on actual development factors.

There have been some studies so far analyzing the impact of public spending -especially that on poverty reduction. Collier and Reinikka used data from a series of household surveys in Uganda 
from 1992 - 99, found that education, access to roads, and access to extension services have a significant positive impact on agricultural production, which has a link with reducing rural poverty [1]. Mafrolla and D'Amico used data from 103 Italian capital municipalities covering the period 2007-2010, revealed that public spending on leisure impacted the spare-time quality of life in various ways, depending on the category of spending [2]. Brown explores the relationship between two seemingly opposing trends of intellectual disabilities and spending restrains to reframe quality of life [3]. It is recommended that we are in need to reframe to quality of life in times of spending restraint to ensure adequate service standards, to use our resources in ways that are most beneficial to people with intellectual disabilities, and to save resources that are not wanted. It is concluded that there can be a mutually beneficial relationship between quality of life and spending restraint if approached wisely. Scully examines the physical quality of life and found the level of government consumption expenditure that provides maximum physical quality of life [4]. It also considers those expenditures that cause equality between marginal benefit and marginal government expenditure out of GNP. It concludes that government consumption expenditure is considerably higher than is necessary to maximize the physical quality of life and that a reduction in government consumption expenditure would not lower quality of life. Fan et. al, of the International Food Policy Research Institute estimated the effects of different types of government expenditure on agricultural growth and rural poverty in Africa [5]. They found that government expenditures on agricultural research and extension services and that on rural roads have an impact on poverty reduction.

These studies in conjunction with some others advocate that public investment must play an even greater role in fostering future economic growth and poverty reduction. However, different types of spending have differential effects on growth and poverty reduction in different countries. At the International Food Policy Research Institute, some more studies have been carried out at the national or local government levels for different countries. Fan et. al, and Mapar and Mazumder on India; Quy on Vietnam; Long et. al on China; and Khaqan et. al on Pakistan refer some of those [6$10]$.

Even though such secondary data are available in Bangladesh, there has been no such previous study to analytically investigate the relationship between public spending and improving the quality of life especially using the channel of agricultural growth or rural development. The objective of this study is to establish a link between public expenditures in different sectors of economy and improvement in the quality of life through the channel of agricultural growth or rural development in Bangladesh. After reviewing related pieces of literature, this paper develops an analytical framework and applies it empirically to analyze the impact of different types of public expenditures on quality of life through rural development between 1982 and 2017.

\section{THE FRAMEWORK OF THE STUDY}

Increases in public expenditure increase aggregate demand in the economy. Demand for labor, being a derived demand, also increases, raising the level of employment and productivity. Higher employment and productivity lead to two paths. One leads to a rise in wages and thus contributing to a reduction in poverty and the other leads to an acceleration in economic growth which in turn leads to a rise in public expenditure. 
Government policy aimed at economic growth, creation of employment and improved wages play a crucial role in reducing poverty and thereby advancement in the quality of life [11]. Among these policies, government expenditures on education, health, infrastructure, and agricultural development have been most influential. Food and housing services are vital tools in this antipoverty program. But very few societies have administered to reduce poverty through direct welfare relocation alone. Education and health expenditures that help increase the employability and productivity of individuals are an indirect but more sustained way of achieving the goal.

Much of the impact of public expenditure can be viewed as setting up infrastructure for economic growth in the broader sense - social infrastructure like education and health, and physical infrastructures like roads and highways, energy and power, and fertilizer [12]. For the market to function smoothly in the growth process, these infrastructures are needed and until now in most cases, it is beyond the capacity of the private sector to provide all these. Therefore, it is usually the government who provides for these infrastructures- and here lies the vital link between public spending and economic development through poverty reduction.

\section{PUBLIC EXPENDITURE IN BANGLADESH: TRENDS AND IMPACT}

With considerable advancement made in primary education in Bangladesh, the enrolment gap between rich and poor has been appreciably narrowing and the gender gap has been abolished. As a result, public spending on primary education is found somewhat pro-poor, in the sense that the poor attain a greater pie of the benefit. The food for education program, which was launched to attract the parents of poor households to send their children to school, proved to have much impact regarding this.

The government's health expenditures are only inadequately pro-poor in the sense that these expenditures were more equitably distributed compared to the distribution of household income or expenditure in the economy. However, one particular component of health spending, namely, child healthcare within the so-called essential services package (ESP) is strongly pro-poor (that is, skewed in favor of the poor).

On the whole, budgetary allocation to education, health and social safety net as ratios of GDP has increased considerably over the last 30 years, and their distribution is also reasonably pro-poor. Unfortunately, poor governance severely compromises the potential of social expenditures to serve the poor in the most efficient as well as equitable manner.

The main problem, however, is that in per capita terms the level of social expenditure remains very low, even by the standards of other poor countries. Part of the reason why budgetary expenditures are low in absolute terms is that the resource base is low given a low per capita income. But even as a proportion of GDP, budgetary expenditure is low in Bangladesh, even by regional standards.

The sectoral distribution pattern of development spending has undergone some noteworthy changes in the last three decades, reflecting the changing developmental priorities of the government under the economic restructurings. Allocations have fallen appreciably for several direct productive sectors: markedly manufacturing, industry, water resources and energy, and agriculture. The turnaround of this structural change in development spending is the increased 
Fardoush, Z. (2020). Impact of Public Spending on the Quality of Life in Rural Bangladesh. Advances in Social Sciences Research Journal, 7(4) 47-61.

relative shares to transport and communication, rural development and social welfare sectors, especially health and education.

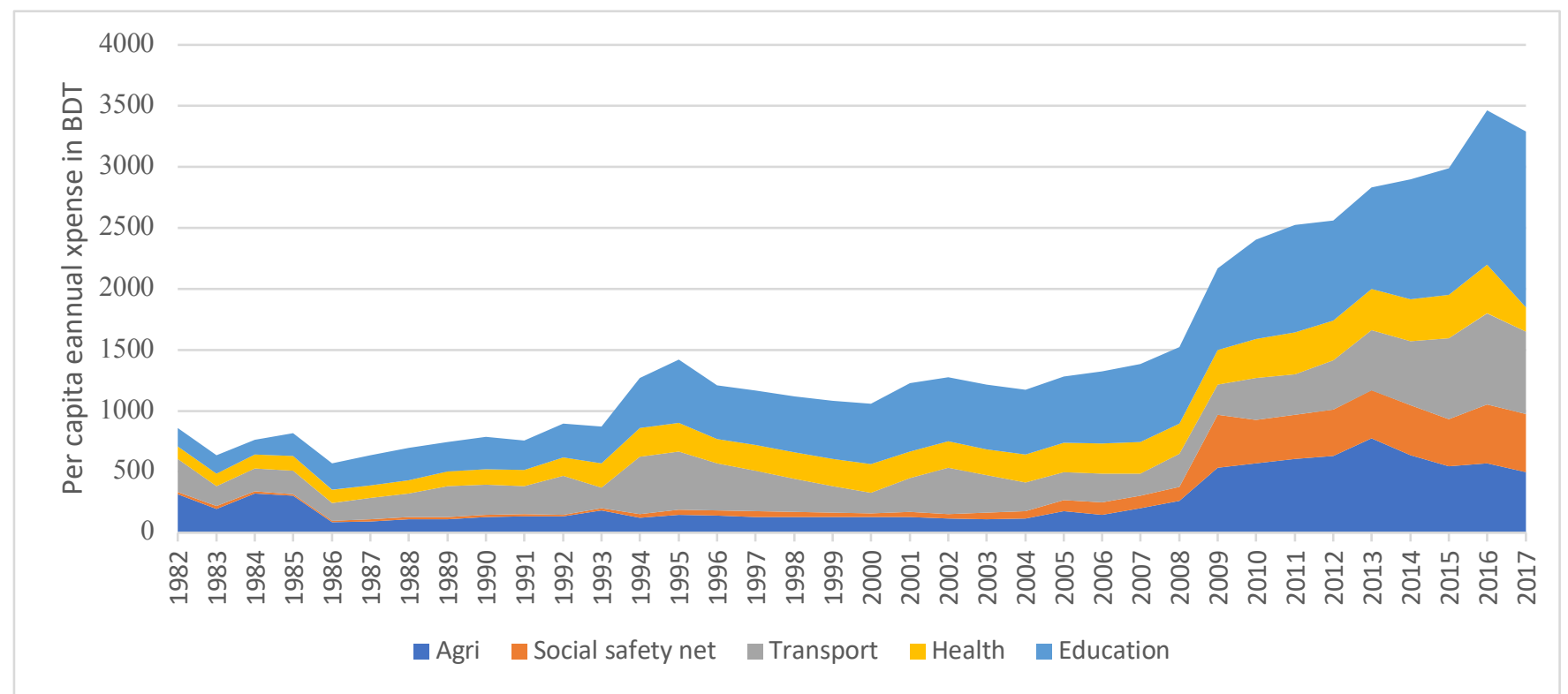

Figure 1: Trends in per capita Public spending (sector-wise)

The proportional allocation of education, social safety net and health has persistently increased throughout the reform period beginning from the early 1980s. Figure 1 shows the trend in per capita public expenditures in various sectors namely agriculture, social safety net, transport, health, and education. It has been revealed that over time per capita public spending increases in all of these sectors. However, the sectoral increasing rate varies over time.

The findings shown in Table 1 imply that education, transport, and agriculture had the highest shares in the 1980s. The share of health surpassed the share in agriculture throughout the 1990s and 2000s. The growth of public expenditures in all of the sectors remarkably increased during 2011-2017. Especially, the growth of social safety nets and transport were notably higher during 2011-2017.

Table 1: Per capita allocation of public spending in different periods (annual average)

\begin{tabular}{rccccc} 
Duration & Agriculture & Social safety net & Transport & Health & Education \\
\hline $\mathbf{1 9 8 2 - 1 9 9 0}$ & 185.02 & 17.01 & 203.68 & 111.79 & 205.68 \\
\hline $\mathbf{1 9 9 1 - 2 0 0 0}$ & 137.38 & 31.85 & 304.32 & 204.47 & 405.46 \\
\hline $\mathbf{2 0 0 1 - 2 0 1 0}$ & 235.93 & 139.14 & 270.41 & 249.00 & 602.27 \\
\hline $\mathbf{2 0 1 1 - 2 0 1 7}$ & 607.76 & 414.26 & 547.75 & 328.89 & 1037.88 \\
\hline
\end{tabular}




\section{METHODOLOGY AND MODEL SPECIFICATIONS}

Simultaneous equation model technique has been used to explore the impacts of public spending in different sectors on improving the quality of life in rural areas through different channels. Three linear equations have been used. It, therefore, turns into a 3-Stage Least Square (3SLS) model which is widely applied to investigate such research questions in the form of a set of linear simultaneous equations.

$$
\operatorname{lnLIFE} E_{t}=\alpha_{0}+\alpha_{1} \operatorname{lnTFPA} A_{t}+\alpha_{2} \ln T F P I_{t}+\alpha_{3} \operatorname{lnTFPM} M_{t}+\alpha_{4} \ln P C S_{-} \text {Cons }_{t}+\alpha_{5} \operatorname{lnSCHOOL_{t}}+u_{t}
$$

\section{Equation 1: Determinants of Quality of Life}

$\operatorname{lnTFPA} A_{t}=\beta_{0}+\beta_{1} \ln P C S_{-}$Agri ${ }_{t}+\beta_{2} \ln P C S_{-} S S_{t}+\beta_{3} \ln P C S_{-} E d u_{t}+\beta_{4} \ln P C S_{-}$Trans $_{t}+\beta_{5} \ln P C S_{-}$Health $_{t}+v_{t}$

\section{Equation 2: Determinants of Agricultural Productivity Growth (TFPA)}

$$
\operatorname{lnSCHOOL} L_{t}=\gamma_{0}+\gamma_{1} \ln P C S_{-} E d u_{t}+\gamma_{2} \ln P C S_{-} \text {Health }_{t}+\gamma_{3} \ln P C S_{-} \text {Trans }_{t}+w_{t}
$$

\section{Equation 3: Determinants of Primary School Enrolment (SCHOOL)}

Where,

$\boldsymbol{L I F E}_{\boldsymbol{t}}=$ Life expectancy, at birth at time $\mathrm{t}$

$\boldsymbol{T F P A}_{\boldsymbol{t}}=$ Value added in agriculture at local currency at time $\mathrm{t}$

$\boldsymbol{T F P I}_{t}=$ Value added in the industry at local currency at time $\mathrm{t}$

$\boldsymbol{T F P M}_{\boldsymbol{t}}=$ Value added in manufacturing at local currency at time $\mathrm{t}$

$\boldsymbol{S C H O O L} \boldsymbol{L}_{t}=$ Enrollment in primary school at time $\mathrm{t}$

$\boldsymbol{P C S}$ Agri $_{\boldsymbol{t}}=$ Per capita public spending in Agriculture at time t (stock value)

$\boldsymbol{P C S} \boldsymbol{S} \boldsymbol{S}_{\boldsymbol{t}}=$ Per capita public spending in Social safety net at time t (stock value)

$\boldsymbol{P C S}_{-}$Trans $_{\boldsymbol{t}}=$ Per capita public spending in Transportation and infrastructure at time t (stock value)

PCS_Health $\boldsymbol{t}_{\mathbf{t}}=$ Per capita public spending in Health at time t (stock value)

$\boldsymbol{P C S} \boldsymbol{E} d u_{t}=$ Per capita public spending in Education at time t (stock value)

$\boldsymbol{\alpha}, \boldsymbol{\beta}$ and $\boldsymbol{\gamma}$ are coefficients while $\mathrm{u}, \mathrm{v}$ and $\mathrm{w}$ are considered as error terms.

The foremost dependent variable of interest is the life expectancy at birth (LIFE), used as a proxy for human development or poverty index which measures the quality of life for rural people of Bangladesh. Life expectancy at birth refers to the number of years a person could expect to live. The explanatory variables are explained below: 


\section{Total Factor of Productivity Growth}

The three TFP variables refer to total factor productivity growth in agriculture, industry, and manufacturing sectors. Some economists support the idea that productivity growth could help in poverty alleviation through income generation and resulted in improved quality of life [13]. The others argue that productivity improvements, especially in agriculture could direct to fast progress in the quality of life as a supply of labor shifts from the agriculture sector towards the industrial sector. The equation will test which sector's TFP is essential in increasing the quality of life for the Bangladesh rural area.

\section{Per Capita Consumption Expenditure}

This variable reflects household final consumption expenditure per capita which also might be a good explanatory variable for the quality of life. A positive relationship between per capita consumption expenditure and quality of life is expected, but the interesting thing here is to determine the impact of consumption expenditure on the life expectancy of any individual. Wilkinson et. al. raises an interesting point that economic growth which is supposed to raise the income of all alone is not necessarily a decent determinant of life expectancy and people's wellbeing [14]. The study depicts that individuals in some developing countries may attain a level of life-expectancy comparable to high-income industrialized nations even when their income may be far lower.

\section{Primary School Enrolment (SCHOOL)}

This variable is embedded in the model to test the impact of education on the quality of life. The Human Development Report of 2003 finds a positive relationship between life expectancy and literacy rate. For this study, Primary school enrolment has been used instead of literacy rate. However, we could expect a positive relationship between life expectancy and the rate of enrolment as well.

The dependent variable for the second equation is agricultural productivity growth. This equation should encompass the factors which could completely explain the growth of TFP in agriculture. The explanatory variables which are tested include public spending on agriculture, education, social safety net, health, and transportation. The variables are explained below:

\section{Per capita Public Spending in Agriculture}

This variable refers to government expenditure in the agriculture sector. This may include the subsidy on agriculture (seeds, fertilizer, electricity, and machinery). Investments in infrastructure, extension services, and Research \& development works are also been included. A positive relationship between the public spending in agriculture and productivity growth is expected subject to higher expected TFP in the agriculture sector compared to the TFPs in industry, manufacturing or service sector.

\section{Per capita Public Spending on Education}

This variable refers to the government expenditure in education that comprises education infrastructure, salaries to teachers, research works. In Bangladesh, education is free till the secondary level and special emphasis has been given to the expenditure on education in rural areas. Again, a positive relationship between the TFP growth in agriculture and spending on education 
could be expected indirectly as better education leads rural farmers to adopt new knowledge and technology in agriculture that would help in an increased TFP.

\section{Per capita Public Spending on Social Safety net}

This variable refers to the government expenditure on social welfare and safety net. This includes rehabilitation expenditure, cash transfer, food for work, etc. The Government has initiated numerous safety net programs that have had some beneficial impact. However, consistent with Bangladesh's level of income, the programs are limited in scale and coverage. This, together with inefficiencies within programs, means that these programs are not adequate for addressing poverty or for mitigating vulnerability to poverty. However, a positive relationship between spending and TFP in agriculture could be expected.

\section{Per capita Public Spending on Transport}

This variable refers to government expenditure in the transport and communication sector. A good transportation system would help the distribution of agriculture crops efficiently. Hence a positive relationship could be expected.

\section{Per capita Public Spending on Health}

This variable refers to public spending in the health sector. This is a very big sector for economic development. This includes the expenditure for the hospital, doctors, research and development, immunization, etc. A better health sector leads to a better labor force, hence a better agriculture sector. So a positive relationship is expected.

The dependent variable is an indication of education advancement. Here the number of primary school enrolments is used. Hence this equation seeks to examine the factors that may explain the disparity in the primary school enrolment rate in Bangladesh. The explanatory variables included in this equation are public spending on education, health, and transport.

\section{Per capita Public Spending on Education}

Studies reveal a positive impact of public spending on education to the advancement in education. Hence, a positive relationship between these two variables seems to be obvious. In Bangladesh, poor regions especially depend on the government's funds for education to improve its educational facilities.

\section{Per capita Public Spending on Transport}

This variable refers to government expenditure in the transport and communication sector. A good transportation system would help the facilitation in education in an efficient way. Hence a positive relationship could be expected.

\section{Per capita Public Spending on Health}

This variable refers to public spending in the health sector. Though any direct positive relationship is not obvious between the spending on health and the number of enrolments in school, this could be tested in this study. 


\section{DESCRIPTION OF DATA}

The data on sector-wise annual public spending by the Government of Bangladesh has been extracted from the Asian Development Bank's Key Development Indicators. The World Development Indicators of the World Bank have been used for the data on indicators of quality of life and TFPs. A time-series data from 1982 to 2017 has been considered. However, for the data on primary school enrollment, the source of the Ministry of Education of Bangladesh has been used.

\section{Description of the variables:}

- Though using Human Development Indicator (HDI) by United Nations Statistics division or Poverty measure would be a better choice as an indicator of Quality of life in rural areas for this study, but long time series data for those were not available. Hence, life expectancy at birth has been used as a proxy variable for that.

- Value addition in agriculture, industry, manufacturing and service sector has been considered as the Total Productivity Factor (TFP) for the respective sectors.

- The number of enrollments in primary school rather than the literacy rate has been taken as an independent variable for quality of life indicator due to the availability of relevant data.

- Public expenditure on all the mentioned sectors has been adjusted for price changes through the GDP deflator (the base year 1996). However, in the final calculation, the per capita annual public spending has been used instead of total annual public spending. It seems that it would be more appropriate to determine the Productivity growth that would turn into a better quality of life to an individual. The idea behind this thought is that, if the Population growth rate is greater than the growth in spending in various sectors then even if the stock public spending increases, but it would not help to improve the quality of life of an individual especially related to Agriculture.

It is then converted into stock values using the following Capital accumulation formula:

$$
\mathrm{K}_{\mathrm{t}}=\mathrm{I}_{\mathrm{t}}+(1-\delta) * \mathrm{~K}_{\mathrm{t}-1}
$$

Where,

$\mathbf{K}_{\mathbf{t}}$ = stock value of the spending in year $\mathrm{t}$;

$\mathbf{I}_{\mathbf{t}}=$ gross capital formation in year $\mathrm{t}$, and

$\boldsymbol{\delta}=$ depreciation rate.

To obtain initial values for the stock (It), the following equation has been used:

$$
\mathrm{K}_{0}=\mathrm{I}_{0} /(\mathrm{r}+\delta)
$$

Here, $r$ refers to the real interest rate. As an approximation and standard practice depreciation rate has been taken as $\delta=10$ percent, while the real interest rate (from WDI) has been used. 


\section{RESULTS AND FINDINGS}

\section{Summary Statistics}

The factors used as an indication and key determinants of quality of life have followed an upward trend as shown in Table 2. Life expectancy has increased at a decreasing rate (which is natural) from 54.3 years in 1982 to 72.8 years in 2017. Growth of agricultural TFP was in the range of 2.8 to 5.1 percent (annual average) throughout the 1982-2017 period. Growth of the service sector's TFP was also moderate ranging from 4.1 to 7.3 percent (annual average). The rate was higher for the manufacturing and industry sectors ranging between 6.7 to 14.1 and 7.7 to 12.9 percent (annual average) respectively. Scholl enrollment has also experienced a growing trend.

Table 2: Summary statistics of the Indicators of Quality of Life

\begin{tabular}{ccccccc}
\hline Duration & $\begin{array}{c}\text { End-period } \\
\text { Life } \\
\text { Expectancy }\end{array}$ & $\begin{array}{c}\text { TFP growth } \\
\text { Agriculture }\end{array}$ & $\begin{array}{c}\text { TFP growth } \\
\text { Manufacturing }\end{array}$ & $\begin{array}{c}\text { TFP } \\
\text { growth } \\
\text { Industry }\end{array}$ & $\begin{array}{c}\text { TFP } \\
\text { growth } \\
\text { Service }\end{array}$ & $\begin{array}{c}\text { School } \\
\text { Enrolment } \\
\text { (maximum in } \\
\text { million) }\end{array}$ \\
\hline $\mathbf{1 9 8 2 - 1 9 9 0}$ & 58.4 & $2.82 \%$ & $6.74 \%$ & $7.66 \%$ & $4.12 \%$ & 11.94 \\
\hline $\mathbf{1 9 9 1 - 2 0 0 0}$ & 65.3 & $3.40 \%$ & $9.50 \%$ & $9.69 \%$ & $5.13 \%$ & 16.71 \\
\hline $\mathbf{2 0 0 1 - 2 0 1 0}$ & 70.1 & $5.11 \%$ & $10.62 \%$ & $10.53 \%$ & $7.25 \%$ & 16.96 \\
\hline $\mathbf{2 0 1 1 - 2 0 1 7}$ & 72.8 & $3.69 \%$ & $14.06 \%$ & $12.86 \%$ & $7.33 \%$ & 19.58 \\
\hline
\end{tabular}

\section{Regression Outputs}

The Regression outputs are given in table 3 in reference to the Equation below:

$$
\ln L I F E_{t}=\alpha_{0}+\alpha_{1} \ln T F P A_{t}+\alpha_{2} \ln T F P I_{t}+\alpha_{3} \ln T F P M_{t}+\alpha_{4} \operatorname{lnPCS} \text { Cons }_{t}+\alpha_{5} \operatorname{lnSCHOOL} L_{t}+u_{t}
$$

\section{Equation 1: Determinants of Quality of Life}

The result of the estimation of equation 1 has been presented in Table 3 .

Table 3: Estimations of coefficients of Equation 1

Dependent variable: InLIFE

\begin{tabular}{cc}
\hline InTFPA & $0.398^{* * *}$ \\
& $(0.118)$ \\
\hline \multirow{2}{*}{ InTFPI } & $0.248^{* * *}$ \\
& $(0.114)$ \\
\hline \multirow{2}{*}{ InTFPM } & $-0.443^{* * *}$ \\
$(0.212)$ \\
\multirow{2}{*}{ InPC_Cons } & $\begin{array}{c}0.110^{* * *} \\
(0.029)\end{array}$ \\
\hline \multirow{2}{*}{ InSCHOOL } & $0.137^{* * *}$ \\
& $(0.039)$ \\
\hline \multirow{2}{*}{ R-square } & 0.989 \\
\hline
\end{tabular}

No of Observation

36

*** refers statistically significance at 1 percent level 


\section{Agricultural Productivity Growth (TFPA)}

The result indicates a positive and significant relationship between agricultural productivity growth and quality of life. It implies that a 1 percent increase in the TFP growth rate in agriculture would increase the life expectancy by 0.398 percent, ceteris paribus. This is following the assumption that productivity growth could help alleviate poverty and thus improve the quality of life through income generation. Similarly, it is also consistent with the analysis of some economists that productivity growth in agriculture could positively affect the quality of life, as agricultural labor is freed up and move to the industrial sector.

\section{Industrial Productivity Growth (TFPI)}

The result shows a positive and significant relationship between industrial productivity growth and quality of life. It depicts that a 1 percent increase in TFP growth in the industry sector would increase the life expectancy by 0.248 percent, ceteris paribus. The major force of this is due to the impact of industries related to agriculture. In recent time, many agro-based SMEs have flourished, which ensure better incomes for the employees and the ultimate result is a better quality in life.

\section{Manufacturing Productivity Growth (TFPM)}

Productivity growth in the manufacturing sector seems to have a significant negative relationship with the quality of life (i.e., Life expectancy). The result implies that a 1 percent point increase in the TFP growth rate in the manufacturing sector, ceteris paribus, would decrease the life expectancy by 0.443 percent. The reason for the negative impact could be explained in terms of environmental pollution or hazards resulted due to the growth of the labor-intensive manufacturing sector in Bangladesh.

\section{Per Capita Consumption Expenditure (PC_cons)}

Results reveal that there exists a negative relationship between consumption expenditure and life expectancy. It shows that a 1 percent increase in per capita consumption expenditure, ceteris paribus, would result in a 0.11 percent decrease in life expectancy.

\section{Primary School Enrolment (SCHOOL)}

A positive and significant relationship between the quality of education and quality of life has been revealed in the result. It seems that all other factors remaining constant a 1 percent increase in the number of primary school enrolment would result in about 0.137 percent increase in life expectancy, ceteris paribus. This outcome is consistent with the findings of the UN Human Development Report of 2003.

$\operatorname{lnTFPA} A_{t}=\beta_{0}+\beta_{1} \ln P C S_{-}$Agri ${ }_{t}+\beta_{2} \ln P C S_{-} S S_{t}+\beta_{3} \ln P C S_{-} E d u_{t}+\beta_{4} \ln P C S_{-}$Trans $_{t}+\beta_{5} \ln P C S_{-}$Health $_{t}+v_{t}$

Equation 2: Determinants of Agricultural Productivity Growth (TFPA)

The result of the estimation of equation 2 has been presented in Table 4 . 
Table 4: Estimations of coefficients of Equation 2

Dependent variable: InTFPA

\begin{tabular}{|c|c|}
\hline InPCS_Agri & $\begin{array}{c}0.104^{* * *} \\
(0.041)\end{array}$ \\
\hline InPCS_SS & $\begin{array}{l}0.075^{* *} \\
(0.039)\end{array}$ \\
\hline LnPCS_Edu & $\begin{array}{c}0.403^{* * *} \\
(0.073)\end{array}$ \\
\hline InPCS_Trans & $\begin{array}{c}-0.111^{* * *} \\
(0.039)\end{array}$ \\
\hline InPCS_Health & $\begin{array}{l}-0.003 \\
(0.063)\end{array}$ \\
\hline R-square & 0.967 \\
\hline No of Observation & 36 \\
\hline
\end{tabular}

\section{Per capita Public Spending in Agriculture}

The result shows a positive relationship between government expenditure in the agricultural sector and the productivity improvement in agriculture. Statistically, a 1 percent increase in per capita public spending in agriculture would result in an increase in agriculture TFP growth by 0.104 percent, ceteris paribus. This variable also comes as statistically significant at $1 \%$. A positive relationship between the public spending in agriculture and productivity growth refers to efficient and well-managed public spending in the agricultural sector in Bangladesh which resulted in increased TFP of this sector.

\section{Per capita Public Spending on Social Safety net}

Result reveals a positive relationship between the per capita public spending on the social safety net and TFP in agriculture, as expected. It seems that all other factors remaining the same, a 1 percent increase in per capita public spending on social safety net would result in a 0.075 percent increase in agriculture TFP. This variable also comes as statistically significant at 5\%.

\section{Per capita Public Spending on Education (PS_E)}

Estimation reveals a positive relationship between the TFP growth in agriculture and spending on education. 1 percent increase in per capita public spending in education would result in a substantial 0.403 percent increase in agricultural TFP, ceteris paribus.

\section{Per capita Public Spending on Health}

A significant positive relationship between per capita public spending on health and agriculture TFP was expected but found with a slight negative elasticity of 0.003 . The estimation, however, is not statistically significant at the 10 percent level. 
Per capita Public Spending on Transport (PS_T)

According to the empirical statistics, there exists a significant negative relationship between government expenditure in the transportation sector and its impact on agricultural productivity growth. All other factors remaining constant, a 1 percent increase in government spending in the transportation sector would result in a decrease in agriculture TFP growth rate by 0.111 percent point. This would reveal the fact that the transportation sector's spending focuses less on rural or agricultural development in Bangladesh.

$$
\operatorname{lnSCHOOL} L_{t}=\gamma_{0}+\gamma_{1} \ln P C S_{-} E d u_{t}+\gamma_{2} \ln P C S_{-} \text {Health }_{t}+\gamma_{3} \ln P C S_{-} \text {Trans }_{t}+w_{t}
$$

\section{Equation 3: Determinants of Primary School Enrolment (SCHOOL)}

The result of the estimation of equation 3 has been presented in Table 5 .

Table 5: Estimations of coefficients of Equation 3

Dependent variable: InSCHOOL

\begin{tabular}{cc}
\hline InPCS_Edu & $\begin{array}{c}0.155^{* * *} \\
(0.056)\end{array}$ \\
\hline InPCS_Trans & $\begin{array}{c}-0.012 \\
(0.044)\end{array}$ \\
\hline InPCS_Health & $\begin{array}{c}0.362^{* * *} \\
(0.076)\end{array}$ \\
\hline R-square & 0.901 \\
\hline No of Observation & 36 \\
\hline$* * *$ refers statistically significance at 1 percent level
\end{tabular}

\section{Per capita Public Spending on Education}

The result shows a positive and significant relationship between public spending in the education sector and the improvement in quality (or participation share) of education in Bangladesh. Considering all other factors the same, a 1 percent increase in public spending in education would result in a 0.155 percent increase in the number of primary school enrolment, on average.

\section{Per capita Public Spending on Transport (PS_T)}

Better transportation would help easier access to education. The result, however, reveals an inverse relationship between per capita public spending in the transportation sector and the number of enrolments in school. The coefficient, however, is not statistically significant.

\section{Per capita Public Spending on Health (PS_H)}

A healthier nation will obtain more education. Result also reveals the same as a statistically significant positive relationship that has been found between spending in health and enrolment in primary school. The significant positive impact states that an increase in 1 percent per capita public spending in health would increase the primary school enrolment by 0.362 percent on average considering all other factors remain constant. 


\section{Impact of Public spending on Life expectancy}

\section{Impact of spending in agriculture}

This is measured as:

$$
\frac{\delta \ln L I F E}{\delta \ln P C S_{\_} A g r i}=\frac{\delta \ln L I F E}{\delta \ln T F P A} \times \frac{\delta \ln T F P A}{\delta \ln P C S_{-} A g r i}=0.398 \times 0.104=0.0414
$$

\section{Impact of spending on Social Safety net}

This is measured as:

$$
\frac{\delta \ln L I F E}{\delta \ln P C S \_S S}=\frac{\delta \ln L I F E}{\delta \ln T F P A} \times \frac{\delta \ln T F P A}{\delta \ln P C S \_S S}=0.398 \times 0.075=0.0299
$$

\section{Impact of spending in Education}

This is measured as:

$$
\begin{aligned}
\frac{\delta \ln L I F E}{\delta \ln P C S_{-} E d u}= & \frac{\delta \ln L I F E}{\delta \ln T F P A} \times \frac{\delta \ln T F P A}{\delta \ln P C S_{-} E d u}+\frac{\delta \ln L I F E}{\delta \ln S C H O O L} \times \frac{\delta \ln S C H O O L}{\delta \ln P C S_{-} E d u} \\
& =0.398 \times 0.403+0.137 \times 0.155=0.182
\end{aligned}
$$

\section{Impact of spending in Health}

This is measured as:

$$
\begin{gathered}
\frac{\delta \ln L I F E}{\delta \ln P C S_{-} \text {Health }}=\frac{\delta \ln L I F E}{\delta \ln T F P A} \times \frac{\delta \ln T F P A}{\delta \ln P C S_{-} \text {Health }}+\frac{\delta \ln L I F E}{\delta \ln S C H O O L} \times \frac{\delta \operatorname{lnSCHOOL}}{\delta \ln P C S_{-} \text {Health }} \\
=0.398 \times 0.0+0.137 \times 0.362=0.050
\end{gathered}
$$

\section{Impact of spending in Transport}

This is measured as:

$$
\begin{aligned}
\frac{\delta \ln L I F E}{\delta \ln P C S_{-} \text {Trans }} & =\frac{\delta \ln L I F E}{\delta \ln T F P A} \times \frac{\delta \ln T F P A}{\delta \ln P C S_{-} \text {Trans }}+\frac{\delta \ln L I F E}{\delta \ln S C H O O L} \times \frac{\delta \ln S C H O O L}{\delta \ln P C S_{-} \text {Trans }} \\
& =0.398 \times(-0.111)+0.137 \times 0.0=-0.044
\end{aligned}
$$

Results show that, except for public spending in transportation, the spending in all other sectors have a positive impact on life expectancy using the channel of TFP in agriculture and school enrolment. The highest impact is due to education which suggests that an increase in public spending in education by 1 percent will result in the increase in life expectancy by 0.182 percent on average considering all other spending remains the same. On the contrary, the minimal impact experiences while spending on social safety nets. The marginal impact here is 0.029 percent. However, the negative impact of spending on transport and communication may suggest that the impact is adverse due to the misallocation or mismanagement of public spending in this sector. 


\section{CONCLUSION AND POLICY RECOMMENDATIONS}

Bangladesh has limited public resources. Using public spending to effectively stimulate economic growth and reduce poverty thus requires the government to use the available funds as efficiently as possible. Yet until now, little information has been available to guide policymakers on how best to allocate scarce public resources.

This paper was an attempt to examine the effectiveness of public spending on agricultural and rural development. In particular, this study focuses on the effect of public spending on the quality of life in Bangladesh. Public spending on education could positively enhance both the literacy rate and hence, could in effect, positively influence the quality of life in Bangladesh. At the same time, spending on health, the social safety net would also be productive. It seems that the government's investment in human capital has a more intense effect on the quality of life of society. This comes what may support the economic theory of human capital as well.

\section{Policy Recommendations}

Perhaps, to grasp the agricultural and rural development, the government should continue to institutionalize the policies that support the education of poor in rural areas. Perhaps, with proper education, the farmers could easily adopt new agricultural technologies that they can use to enhance the productivity in their production. This is, of course, subject to the proper use of public spending in agriculture. Maybe rather than giving subsidies in fertilizer or agricultural machinery, it would be better to spend building up capacity for agriculture at this moment. More allocation could be channelized into the R\&D of agriculture. The increase in agricultural productivity could then help alleviate poverty through income generation and may also free up some agricultural labor which can be channeled to the industrial sector and thus, could potentially lead to the overall improvement of quality of life in the country. Besides, the regular welfare spending on health and social safety net would be increased. Transportation should have a substantial impact on ensuring better education for all. But it should be allocated more proportionately to foster decentralization.

\section{References}

1. Collier, P. and Reinikka, R., 2001. Reconstruction and liberalization: An overview. Uganda's recovery: The role of farms, firms, and government, pp.15-48.

2. Mafrolla, E. and D'Amico, E., 2016. Does public spending improve citizens' quality of life? An analysis of municipalities' leisure supply. Local Government Studies, 42(2), pp.332-350.

3. Brown, I., 1999. Embracing quality of life in times of spending restraint. Journal of Intellectual and Developmental Disability, 24(4), pp.299-308.

4. Scully, G.W., 2001. Government expenditure and quality of life. Public Choice, 108(1-2), pp.123-145.

5. Fan, S., Hazell, P. and Thorat, S., 2000. Government spending, growth and poverty in rural India. American journal of agricultural economics, 82(4), pp.1038-1051.

6. Fan, S., Johnson, M., Saurkar, A. and Makombe, T., 2008. Investing in African agriculture to halve poverty by 2015. Intl Food Policy Res Inst.

7. Maparu, T.S. and Mazumder, T.N., 2017. Transport infrastructure, economic development and urbanization in India (1990-2011): Is there any causal relationship?. Transportation research part A: policy and practice, 100, pp.319-336.

8. Quy, N.H., 2017. The Role of Public Expenditures in Economic Growth at Provincial Level: Empirical Study in Vietnam. J. Pol. \& L., 10, p.88. 
9. Long, H., Tu, S., Ge, D., Li, T. and Liu, Y., 2016. The allocation and management of critical resources in rural China under restructuring: Problems and prospects. Journal of Rural Studies, 47, pp.392-412.

10. Khaqan, S.H., Mukhtiar, A. and ur Rehman, A., 2016. Analysis of infrastructure investment and institutional quality on living standards: a case study of Pakistan (1990-2013). Pakistan Development Review, 55(4), pp.315-329.

11. Diener, E., Oishi, S. and Lucas, R.E., 2015. National accounts of subjective well-being. American Psychologist, 70(3), p.234.

12. Kumari, A. and Sharma, A.K., 2017. Physical \& social infrastructure in India \& its relationship with economic development. World Development Perspectives, 5, pp.30-33.

13. Majid, N., 2004. Reaching Millennium Goals: How well does agricultural productivity growth reduce poverty? (No. 2004-12). International Labour Office.

14. Wilkinson, R.G., Pickett, K.E. and De Vogli, R., 2010. Equality, sustainability, and quality of life. Bmj, 341, p.c5816 